\title{
ASSESSMENT OF FOREST DISTURBANCES AND CARBON STOCK IN PANTABANGAN-CARRANGLAN WATERSHED, PHILIPPINES USING REMOTE SENSING
}

\author{
J. J. V. Dida ${ }^{1 *}$, C. L. Tiburan Jr. ${ }^{1}$, and I. Saizen ${ }^{2}$ \\ ${ }^{1}$ Institute of Renewable Natural Resources, College of Forestry and Natural Resources, University of the Philippines Los Baños, \\ College, Laguna 4031 Philippines - (jvdida, cltiburan)@up.edu.ph \\ ${ }^{2}$ Laboratory of Regional Planning, Graduate School of Global Environmental Studies, Kyoto University, Kyoto, 606-8501 Japan - \\ saizen.izuru.4n@kyoto-u.ac.jp
}

KEY WORDS: Forest Disturbance, Carbon Stock Estimation, InVEST, Remote Sensing, Watershed

\begin{abstract}
:
Forest disturbances contribute to the decrease in carbon sequestration potential and ecosystem services in a watershed. One of the important watersheds that is affected by land use changes and disturbances is the Pantabangan-Carranglan Watershed. The ability of the watershed to provide ecosystem services is affected by the existing land use and land cover (LULC) and its future trends. Therefore, this study aims to assess the changes in the LULC, forest disturbances, and potential carbon stock in the watershed using satellite images. The LULC types and indices used in detecting forest disturbances were classified and generated from the Landsat 8 satellite images covering two different years. The potential carbon storage in the watershed was estimated using the Integrated Valuation of Ecosystem Services and Tradeoffs (InVEST) Carbon model. The information generated can be used in the conduct of valuation studies and land use planning in the watershed.
\end{abstract}

\section{INTRODUCTION}

In the Philippines, changes in the watershed land use and land cover (LULC) are affected by several factors. In the case of the country's forest cover, shifting cultivation and migration led to its downward trend (Macandog et al., 2006). The disturbances in the forest, which may also include harvesting and construction activities, contribute to the decrease in carbon sequestration potential and ecosystem services. The conversion of a natural system like the forest into a managed system results to carbon imbalance (Toru and Kibret, 2019). Furthermore, these disturbances will impact the forest cover, components, and biodiversity ( $\mathrm{Hu}$ and $\mathrm{Hu}, 2020)$. Changes in the forest cover has been observed in several areas in the Philippines. From 2001 to 2010, the Sierra Madre Forest experienced forest losses (Perez et al., 2020). The province Zamboanga del Norte has been identified as a deforestation hotspot based on LULC models (Jardeleza, Gotangco, and Guzman, 2019). The forest cover of Mount Pulag National Park decreased from 1990 to 2020 due to human interventions (Doyog, Lumbres and Baoanan, 2021).

One of the important watershed forest reservations affected by land use changes and disturbances in the Philippines is the Pantabangan-Carranglan Watershed. Not only because it is adjacent to the Sierra Madre Mountain Range, but the watershed is also one of the protected areas under the National Integrated Protected Areas System. The ability of the watershed to provide ecosystem services is very much affected by the current LULC and its future trends. Land use dynamics including land use future trends are major factors affecting terrestrial carbon (Fitts et al., 2021). Changes in land use can affect the residual vegetation, soil organic carbon, and the other carbon pools of an ecosystem.

The evaluation of carbon is necessary since there is an increasing demand for countries to assess their contributions. It also serves as an indicator for reducing carbon emissions. Potential carbon storage and sequestration can be computed using software and models. One of the models that is suited for understanding carbon dynamics as a function of possible LULC changes is the Integrated Valuation of Ecosystem Services and Tradeoffs (InVEST) Carbon model (Sadat, Zoghi, and Malekmohammadi, 2019). Given the role of the watershed in providing ecosystem services, the monitoring of LULC changes, forest disturbance, and potential carbon stock changes in the PantabanganCarranglan Watershed becomes an important activity.

Earth observation technology such as satellite images can be used to evaluate changes in vegetation (Hladky et al., 2020). Remote sensing is cost effective and a rapid way of acquiring information over a large geographical area. It also offers accurate data for analysis and serves as a large archive of historical data. This technology has been utilized already in some watersheds in the Philippines. Satellite images, like Landsat 8 multispectral images, were used to assess the LULC changes in the Mount Makiling Forest Reserve from 1992 to 2015 (Soriano et al., 2019). The data is easy to manipulate and combine with other geographic datasets. Landsat 8 is currently the latest satellite that has been launched into orbit. It has been utilized in various fields like forestry and agriculture. Furthermore, satellite images have the capability to delineate the spatial arrangement of different LULC classes (Gupta et al., 2017).

It is also possible to generate spectral indices from Landsat satellite images that can detect forest disturbances. Different indices using Landsat time series data were incorporated in the multispectral ensemble to detect forest disturbances in Argentine Dry Chaco (De Marzo et al., 2021). Studies have already demonstrated the normalized difference moisture index (NDMI) as a good index in detecting forest disturbances. The NDMI from Landsat bands was able to identify forest disturbances in Maine (Jin and Sader, 2005), Polish Tatra Mountains (Ochtyra, 2020), and South Florida (Zhang et al., 2016). Other authors have noted the sensitivity of water content indices to upper plant canopy changes which is a good indicator for disturbances (Ochtyra, 2020). 
In Pantabangan-Carranglan Watershed, the estimation of carbon storage and detection of forest disturbances on a watershed scale has not been explored yet. The study investigated the LULC changes and forest disturbances in the watershed and their effects on the potential carbon stock.

\section{MATERIALS AND METHODS}

The Pantabangan-Carranglan Watershed is part of the towns of Pantabangan and Carranglan in the province of Nueva Ecija (Figure 1). Some areas of the watershed are in within the provinces of Nueva Vizcaya and Aurora. The vegetation of the area is predominantly second growth with patches of primary forests (Peras et al., 2008).

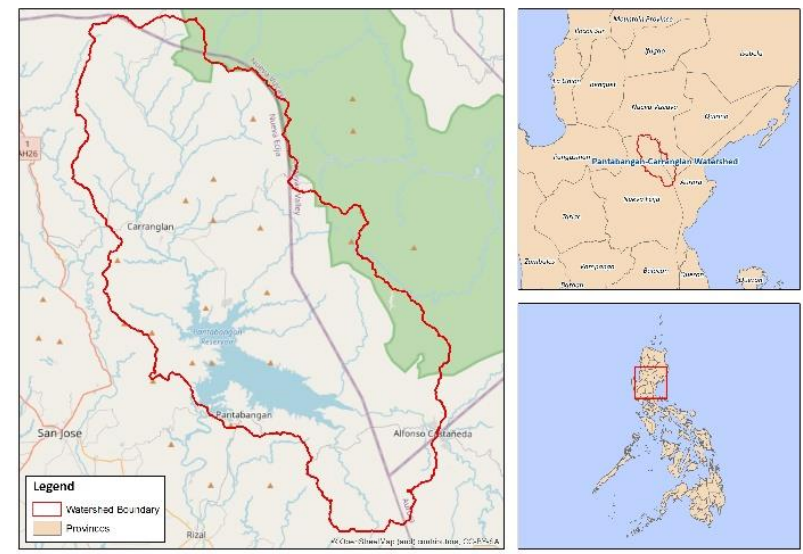

Figure 1. Location of the Study Area. Base map: (C) OpenStreetMap contributors.

The watershed covers a total land area of 97,318 hectares and supports a multi-purpose dam for irrigation and hydroelectric generation. It also provides water for domestic and industrial uses.

\subsection{Image Classification and Change Detection}

Land use/land cover (LULC) types were classified from the Landsat 8 Operational Land Imager (OLI) satellite images. To capture the changes in the area over time, the Google Earth Engine Platform was used to generate stacked images covering the years 2014 and 2020 (Figure 2).
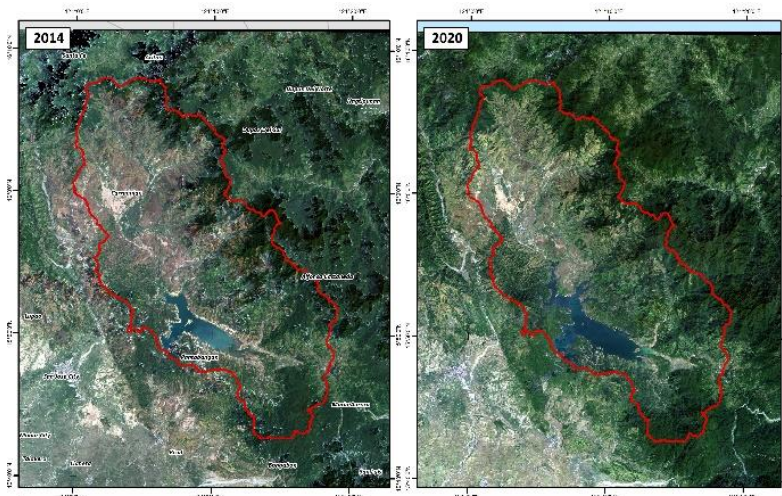

censend

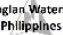

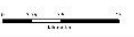

Figure 2. Landsat 8 OLI mosaicked multispectral imagery of Pantabangan-Carranglan Watershed for 2014 and 2020.
The atmospheric correction and cloud masking process were incorporated in the Google Earth Engine processing. The Landsat 8 acquisition dates for the mosaicking of cloudless pixels were set to one year range. The regions of interests (ROI) representing the different LULC types (Built up, Agriculture, Open/Barren, Grassland, Forest, Water) were obtained from the Google Earth Pro through visual interpretation. The Spectral Angle Mapper (SAM) algorithm of the QGIS Semi-Automatic Classification Plugin (SCP) was used in the supervised classification. This algorithm is based on identifying pixel spectra through its angular information where the length of the vector increases or decreases according to the overall illumination, but its angular orientation will remain constant (Riad et al., 2020). The SCP plugin and SAM algorithm were also used to generate the LULC in Silang-Santa Rosa and Pagsanjan-Lumban watersheds (Dida et al., 2021). An accuracy assessment using the confusion matrix was used to determine the quality of the map produced from the remotely sensed images. Random points for each LULC class were obtained from Google Earth Pro and set as the reference image.

\subsection{Disturbance Detection}

Indices based on the satellite image bands were generated and used in detecting forest disturbances in the watershed. Specifically, the Near Infrared (NIR) and Shortwave Infrared (SWIR) bands were used as inputs to generate the normalized difference moisture indices (NDMI). The ratio of NIR and SWIR bands and ground observations of forest damage shows a good correlation (Jin and Sader, 2005). Several studies have also highlighted the performance of NDMI in documenting disturbance on forests (Zhang et al., 2016). The NDMI index used in the study is derived from the NIR and SWIR bands of the Landsat 8 OLI sensor $(\mathrm{Gao}, 1996)$.

$$
N D M I=\frac{N I R(5)-S W I R(6)}{N I R(5)+S W I R(6)}
$$

The NDMI images for 2014 and 2020 were generated using the Band Calculator tool of the SCP plugin. Pixels with negative NDMI values were extracted from the resulting image to identify the areas with disturbance.

\subsection{Estimation of Potential Carbon}

The potential carbon stock of the watershed was estimated using the Integrated Valuation of Ecosystem Services and Tradeoffs (InVEST) Carbon model developed by the Natural Capital Project of Stanford University. The Carbon model estimated the total carbon stock based on assigned carbon pool stocks (aboveground biomass, belowground biomass, soil carbon, and dead organic matter) of different LULC classes. The InVEST Carbon model required carbon pool estimates for each LULC type (Sharp et al., 2020).

$$
C_{\text {total }}=C_{\text {above }}+C_{\text {below }}+C_{\text {dead }}+C_{\text {soil }}
$$

It is assumed in the model that the carbon density of all LULC types is constant, and the carbon changes are only caused by changes in the LULC (Zhao et al., 2018). Previous studies, including available literature, were used as the basis in assigning carbon pool values to each LULC. The aboveground biomass estimates of Macandog et al. (2006) for Philippine forests were used in the model. For the belowground biomass and soil carbon values, the 2006 IPCC report was used as a reference for the rootshoot ratio and regional soil carbon estimates. The computed carbon pool values for agriculture and grassland LULC classes 
were taken from the estimated values in Wahig-Inabanga Watershed in Bohol, Philippines (Reyes and Ludevese, 2015). The dead matter carbon pool values used in the model were from the estimates in Mount Makiling Forest Reserve (Lasco et al. 2004). The built-up, barren, and water LULC classes were assigned zero for the carbon pool values. These values were previously used in the estimation of potential carbon stock in Silang-Santa Rosa and Pagsanjan-Lumban watersheds using InvEST (Dida et al., 2021). The resulting maps of the model are expressed in terms of Megagram $(\mathrm{Mg})$ or Tons of carbon per grid cell.

\section{RESULTS AND DISCUSSIONS}

\subsection{Land Use/Land Cover Changes}

The most dominant land use/land cover (LULC) for 2014 is open/barren land followed by forest. On the other hand, the most dominant LULC for 2020 is forest followed by grassland (Figure 3 ). Based on the change detection, there was an increase in the grassland and forest areas from 2014 to 2020.

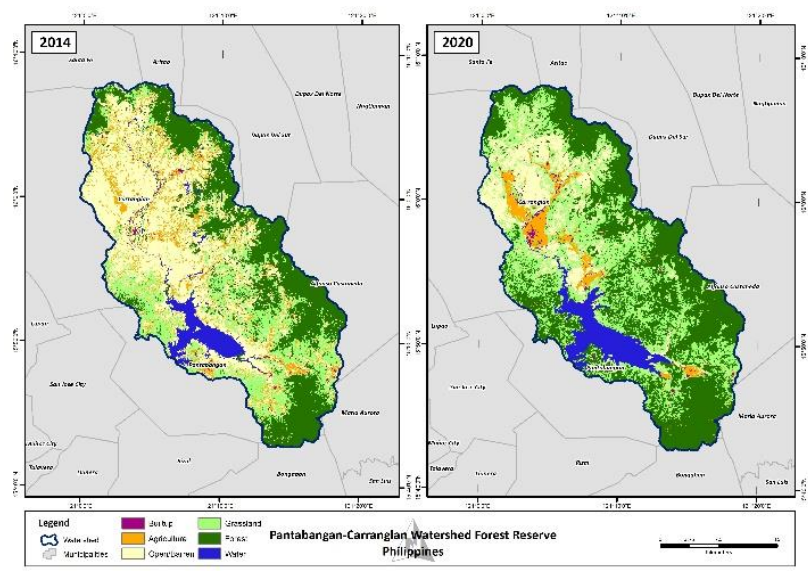

Figure 3. Classified Land Use/Land Cover of PantabanganCarranglan Watershed for 2014 and 2020.

The grassland and open/barren LULC types contributed the most to the forest increment (Table 1). On the other hand, the barren/open and agricultural areas contributed the most to the increase in grassland areas.

\begin{tabular}{|c|c|c|c|c|c|c|c|}
\hline \multirow{2}{*}{2014} & \multicolumn{7}{|c|}{2020} \\
\hline & 1 & 2 & 3 & 4 & 5 & 6 & Total \\
\hline 1 & 0 & $\begin{array}{l}109.7 \\
1\end{array}$ & 5.4 & 0 & 1.08 & 0 & $\begin{array}{l}116.1 \\
9 \\
\end{array}$ \\
\hline 2 & $\begin{array}{l}3389 . \\
94\end{array}$ & 34.92 & $\begin{array}{l}111.7 \\
8\end{array}$ & 76.14 & $\begin{array}{l}153.7 \\
2\end{array}$ & 22.5 & 3789 \\
\hline 3 & $\begin{array}{l}141.7 \\
5\end{array}$ & $\begin{array}{l}23071 \\
.59\end{array}$ & $\begin{array}{l}737.0 \\
1\end{array}$ & 42.75 & $\begin{array}{l}306.7 \\
2\end{array}$ & 13.59 & $\begin{array}{l}24313 \\
.41\end{array}$ \\
\hline 4 & 12.69 & $\begin{array}{l}8640 . \\
99\end{array}$ & $\begin{array}{l}6653 . \\
88\end{array}$ & $\begin{array}{l}229.1 \\
4\end{array}$ & 51.12 & 17.28 & $\begin{array}{l}15605 \\
.1\end{array}$ \\
\hline 5 & $\begin{array}{l}1889 . \\
55\end{array}$ & $\begin{array}{l}3741 . \\
03\end{array}$ & $\begin{array}{l}13791 \\
.24\end{array}$ & $\begin{array}{l}11362 \\
.41\end{array}$ & $\begin{array}{l}2307 . \\
6\end{array}$ & $\begin{array}{l}396.9 \\
9\end{array}$ & $\begin{array}{l}33488 \\
.82\end{array}$ \\
\hline 6 & $\begin{array}{l}120.9 \\
6\end{array}$ & $\begin{array}{l}901.5 \\
3\end{array}$ & $\begin{array}{l}4490 . \\
19\end{array}$ & $\begin{array}{l}1329 . \\
57\end{array}$ & $\begin{array}{l}923.2 \\
2\end{array}$ & $\begin{array}{l}236.1 \\
6\end{array}$ & $\begin{array}{l}8001 . \\
63\end{array}$ \\
\hline Total & 21.33 & 20.7 & 86.67 & 52.65 & 91.53 & $\begin{array}{l}147.3 \\
3\end{array}$ & $\begin{array}{l}420.2 \\
1\end{array}$ \\
\hline
\end{tabular}

Table 1. Cross tabulation of LULC classes (1-water, 2-forest, 3-grassland, 4-open, 5-agriculture, 6-builtup) of PantabanganCarranglan Watershed between 2014 and 2020.
Most of the increase in forest and grassland was observed in the Municipality of Carranglan. The increase was also observed in the southeastern portion of the Municipality of Pantabangan. The forests in the towns of Alfonso Castaneda and Dupax Del Sur remained intact. In a study conducted by Dolores et al. (2020), around $22 \%$ of the watershed are suitable areas for reforestation interventions. The increase in the reforestation areas may have contributed to the changes in grassland and forest areas. Other activities conducted by the Department of Environment and Natural Resources (DENR) in the area through the years include plantation and agroforestry establishment (Ancog, Florece and Nicopior, 2016). The accuracy assessment yielded acceptable overall accuracy values for both 2014 (87.38\%) and 2020 $(86.87 \%)$ LULC images.

\subsection{Disturbances in the watershed}

The normalized difference moisture index (NDMI) values for 2014 ranged from -0.59 to 0.57 . For 2020 , the NDMI values ranged from -0.36 to 0.76 (Figure 4 ).

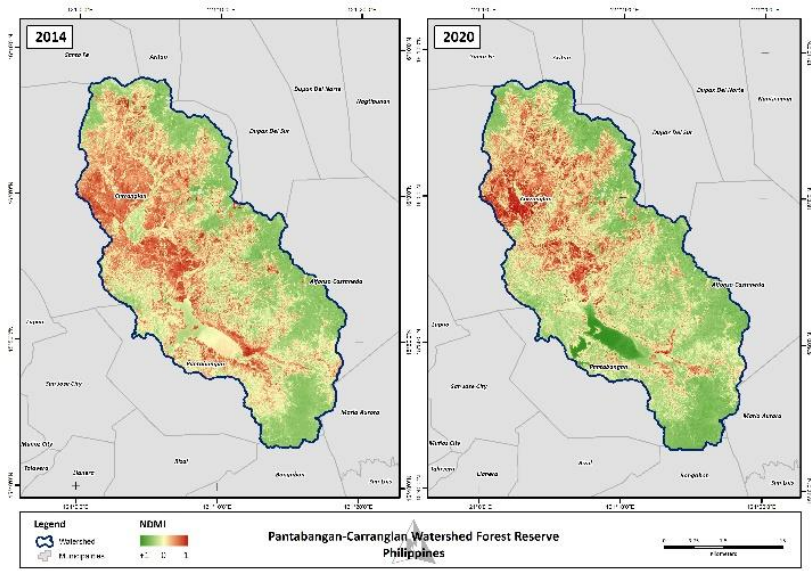

Figure 4. NDMI in Pantangan-Carranglan Watershed based on Landsat 8 for 2014 and 2020 .

The high value of NDMI shows that the area has moist soil surface and very good ground water potential (Sahu, 2014). On the other hand, the values are expected to be negative for most bare soils (Gao, 1996). Since NDMI is connected to the liquid water molecules in vegetation canopies, areas with forest disturbance will have low NDMI values. Most of these areas are found in the Municipality of Carranglan, followed by Pantabangan for both 2014 and 2020 images. (Figure 5).

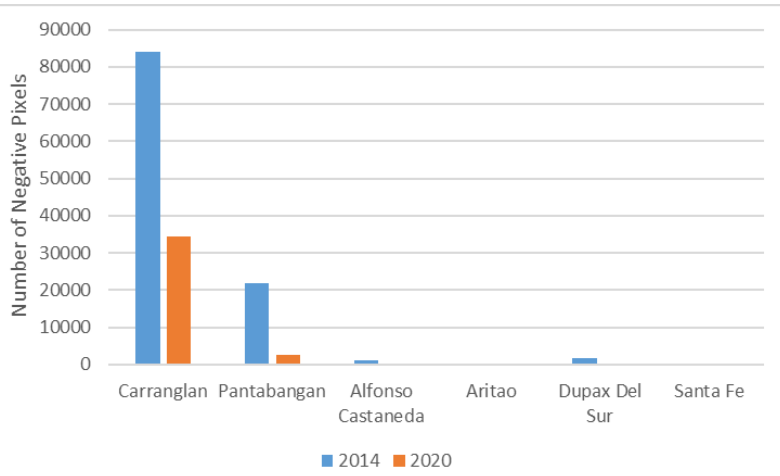

Figure 5. Number of negative NDMI pixels per town in Pantangan-Carranglan Watershed for 2014 and 2020. 
Some of the disturbances that were noted in the area include slash and burning, illegal logging, and livestock grazing (Pabico et al., 2021). The areas with low NDMI decreased from 2014 to 2020 , agreeing to the observed increase in grassland and forest LULC in the watershed. The decrease in the open/barren areas in the northwestern part of the watershed contributed to the decrease in NDMI values. Since NDMI is sensitive to defoliation and damage (Zhang et al., 2016), the reforestation activities and agroforestry establishment may have contributed to its decrease. Interventions that improve the soil moisture and vegetation will yield high positive NDMI values.

\subsection{Potential Carbon Stock Changes}

The estimated total carbon stock in Pantabangan-Carranglan Watershed for 2014 is around 16,476,643.12 Tons of Carbon while the estimated total carbon for 2020 is around 25,184,818.88 Tons of Carbon (Figure 6). Each raster pixel shows the sum of all the carbon pools (Sharp et al., 2020). The total carbon stock values were processed in the InVEST model according to the pixel size of the input raster file.

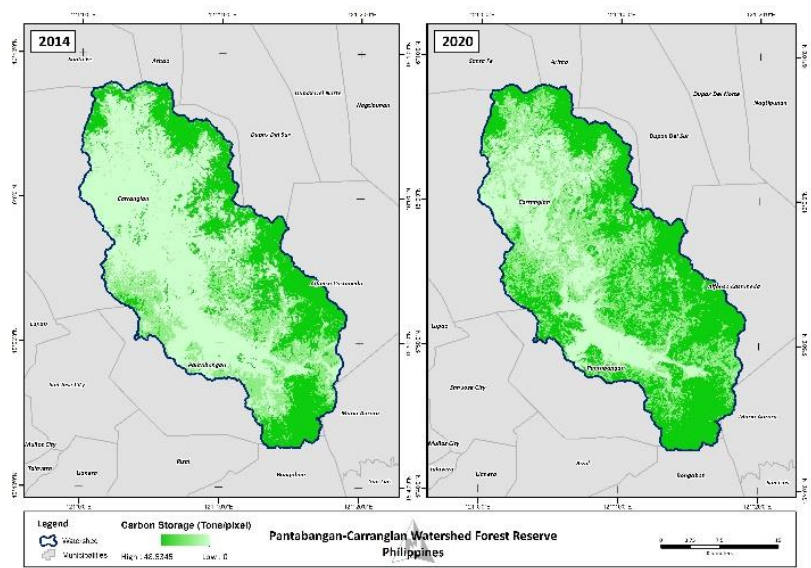

Figure 6. Estimated potential carbon stock in PantanganCarranglan Watershed for years 2014 and 2020.

Among the different towns in the watershed, the Municipality of Carranglan has the highest total estimated carbon stock, followed by the Municipality of Pantabangan. Among the different LULC types, the forest and grassland contributed to the high carbon stock values in the watershed (Figure 7). On the contrary, water, open/barren, and agriculture had very minimal contribution to the total carbon stock.

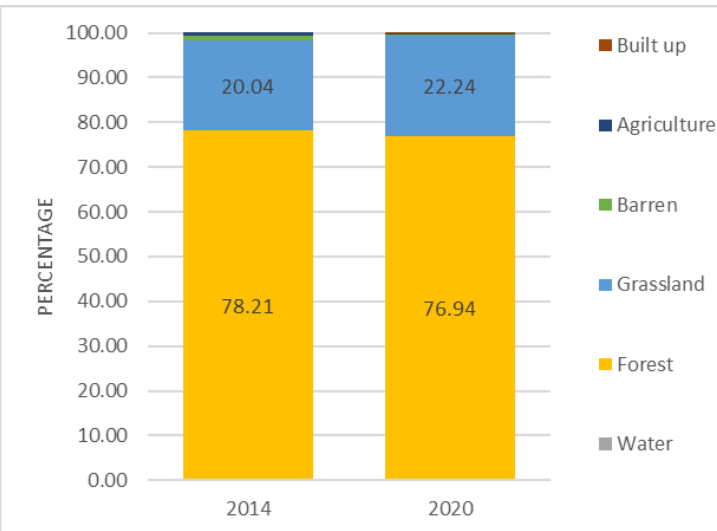

Figure 7. Estimated carbon stock contribution (percentage) of each LULC type in Pantangan-Carranglan Watershed.
Based on the values generated by the carbon modeler and zonal statistics, there was an increase in the estimated total carbon stock from 2014 to 2020 . The total carbon stock increase can be attributed to the decrease in the total area of LULC classes with low carbon pool values, such as open/barren areas. The increase in total carbon stock was also noted in areas (northwestern areas) where the NDMI values decreased. In the eastern side of the watershed (Dupax Del Sur and Alfonso Castaneda), the high carbon stock values did not change from 2014 to 2020. It shows minimal to zero forest LULC changes in the areas (Alfonso Castaneda, Dupax Del Sur, Carranglan) adjacent to the Sierra Madre Mountain Range. Since the forest LULC class had high carbon pool values in the InVEST model, these areas contributed to the total carbon stock in the watershed. Consequently, the reduction of forest and grassland will also lead to total carbon stock loss. Forest disturbance caused by LULC changes may also negatively affect the total carbon of the watershed. Even though the model did not consider the ecological processes in estimating the total carbon storage, the InVEST Carbon model provided a carbon estimate for the watershed that can be used in future valuation and planning activities.

\section{CONCLUSION AND RECOMMENDATIONS}

The study was able to show the potential changes in the carbon dynamics as an effect of LULC changes and forest disturbances. Based on the land use/land cover (LULC) classification process of Landsat 8 images, there was an increase in the grassland and forest areas in Pantabangan-Carranglan Watershed from 2014 to 2020. Reforestation, plantation, and agroforestry establishment, and other human interventions may have contributed to the increase. The LULC changes from 2014 to 2020 agreed to the changes in the NDMI values. The decrease in open/barren areas matched the decrease in forest disturbances. The InVEST model showed that the contribution of forest and grassland areas to the total carbon stock in the watershed. The increase in forest areas from 2014 to 2020 resulted to the increase in total carbon stock. The decrease in the NDMI, an indicator of forest disturbances, matched the reduction of open/barren LULC classes from 2014 to 2020 .

The use of other classification algorithm can be explored to improve the LULC map. Likewise, field validation activities will improve the accuracy of forest disturbance detection and LULC. Due to the absence of actual carbon pool estimates in the area, the study utilized regional carbon estimates. Thus, there is the need to conduct actual biomass estimation in the watershed for more precise carbon pool values. The NDMI maps need to be validated on the ground to determine the threshold values that represent actual forest disturbances. The frequency of forest disturbance also depends on the existing physical factors and protection activities (Ochtyra, 2020). The InVEST Carbon model is dependent on the pixel size of input LULC raster file. Using high-resolution satellite images will further refine the NDMI and carbon stock values. It will show a better representation of the LULC and total carbon storage. To have a good estimate of the value of carbon in the watershed, the valuation model can be processed in the InVEST Carbon model.

\section{ACKNOWLEDGEMENTS}

The authors would like to extend their gratitude to the Graduate School of Global Environmental Studies (GSGES), Kyoto University for supporting the study through the GSGES Seeds Research Funding Program. 


\section{REFERENCES}

De Marzo, T., Pflugmacher, D., Baumann, M., Lambin, E.F., Gasparri, I., and Kuemmerle, T. 2021. Characterizing forest disturbances across the Argentine Dry Chaco based on Landsat time series. International Journal of Applied Earth Observation and Geoinformation, $\quad 98, \quad 102310$ doi.org/10.1016/j.jag.2021.102310.

Dida, J.J.V., Tiburan, C.L.Jr., Tsutsumida, N., and Saizen, I. 2021. Carbon Stock Estimation of Selected Watersheds in Laguna, Philippines Using InVEST. Philippine Journal of Science, 150(2), 501-513.

Dolores, J.C., Galang, M.A., Dida, J.J.V. 2020. Species-site Suitability Assessment of Native Species in PantabanganCarranglan Watershed Using Geographic Information System (GIS) and Analytic Hierarchy Process (AHP). Philippine Journal of Science, 149(3), 529-537.

Doyog, N.D., Lumbres, R.I.C. and Baoanan, Z.G. 2021. Monitoring of Land Use and Land Cover Changes in Mt. Pulag National Park Using Landsat and Sentinel Imageries. Philippine Journal of Science, 150(4), 723-734.

Fitts, L.A., Russell, M.B., Domke, G.M., and Knight, J.K. 2021. Modeling land use change and forest carbon stock changes in temperate forests in the United States. Carbon Balance and Management, 16, 20. doi.org/10.1186/s13021-021-00183-6.

Gao, B.C. 1996. NDWI: A Normalized Difference Water Index for Remote Sensing of Vegetation Liquid Water from Space. Remote Sensing of Environment, 58(3), 257-266.

Gupta, S., Nainwal, A., Anand, S., and Singh, S. 2017. Valuation of Carbon Sequestration in Bidhalna Microwatershed, Uttarakhand, India using InVEST Model. International Journal of Advancement in Earth and Environmental Sciences, 5(1), 1015. doi.org/10.13140/RG.2.2.29675.90404.

Hladky, R., Lastovicka, J., Holman, L., Stych, P. 2020. Evaluation of the influence of disturbances on forest vegetation using Landsat time series; a case study of the Low Tatras National Park. European Journal of Remote Sensing, 53(1), 4066. doi.org/10.1080/22797254.2020.1713704.

Hu, Y. and Hu, Y. 2020. Detecting Forest Disturbance and Recovery in Primorsky Krai, Russia, Using Annual Landsat Time Series and Multi-Source Land Cover Products. Remote Sensing, 12, 129. doi.org/10.3390/rs12010129.

Intergovernmental Panel on Climate Change (IPCC). 2006. Guidelines for National Greenhouse Gas Inventories. Agriculture, Forestry and Other Land Use V 4

Jardeleza, J. M., Gotangco, C. K. and Guzman, M.A.L. 2019. Simulating National-scale Deforestation in the Philippines Using Land Cover Change Models. Philippine Journal of Science, 148(4), 597-608.

Jin, S. and Sader, S.A. 2005. Comparison of time series tasseled cap wetness and the normalized difference moisture index in detecting forest disturbances. Remote Sensing of Environment, 94(3), 364 - 372. doi.org/10.1016/j.rse.2004.10.012.

Lasco, R.D., Guillermo, I.Q., Cruz, R.V.O., Bantayan, N.C., and Pulhin, F.B. 2004. Carbon Stocks Assessment of a Secondary
Forest in Mount Makiling Forest Reserve, Philippines. Journal of Tropical Forest Science, 16(1), 35-45.

Macandog D.B., Delgado M.E.M., Ty E., Villarin J.R.T. 2006. A GIS-Based Model to Improve Estimation of Aboveground Biomass of Secondary Forests in the Philippines. Journal of Tropical Forest Science, 18(1), 8-21.

Ancog, R.C., Florece, L.M., Nicopior, O.B.S. 2016. Fire occurrence and fire mitigation strategies in a grassland reforestation area in the Philippines. Forest Policy and Economics, 64, 35-45. doi.org/10.1016/j.forpol.2016.01.002.

Ochtyra, A. 2020. Forest Disturbances in Polish Tatra Mountains for 1985-2016 in Relation to Topography, Stand Features, and $\begin{array}{llll}\text { Protection Zone. } & \text { Forests, } & \text { 11(5), }\end{array}$ doi.org/10.3390/f11050579.

Pabico, L.A., Duya, M.V., Fidelino, J.S., Ong, P.S., and Duya, M.R.M. 2020. Bird Feeding Guild Assemblage along a Disturbance Gradient in the Pantabangan-Carranglan Watershed and Forest Reserve, Central Luzon Island, Philippines. Philippine Journal of Science, 150(S1), 237-255.

Peras, R.J.J., Pulhin, J.M., Lasco, R.D., Cruz, R.V.O., and Pulhin, F.B. 2008. Climate Variability and Extremes in the Pantabangan-Carranglan Watershed, Philippines: Assessment of Impacts and Adaptation Practices. Journal of Environmental Science and Management, 11(2), 14-18.

Perez, G.J., Comiso, J.C., Aragones, L.V., Merida, H.C., and Ong, P.S. 2020. Reforestation and Deforestation in Northern Luzon, Philippines: Critical Issues as Observed from Space. Forests, 11(10), 1071. doi.org/10.3390/f11101071.

Reyes, T.D.Jr. and Ludevese, E.G. 2015. Rapid Carbon Stock Appraisal (RACSA) Implementation in Wahig-Inabanga Watershed, Bohol, Philippines. International Journal of Environmental and Rural Development, 6(2), 102-109.

Riad, P., Graefe, S., Hussein, H., and Buerkert, A. 2020. Landscape transformation processes in two large and two small cities in Egypt and Jordan over the last five decades using remote sensing data. Landscape and Urban Planning, 197, 103766. doi.org/10.1016/j.landurbplan.2020.103766.

Sadat, M., Zoghi, M., and Malekmohammadi, B. 2019. Spatiotemporal modeling of urban land cover changes and carbon storage ecosystem services: case study in Qaem Shahr County, Iran. Environment, Development and Sustainability, 22, 8135-8158. doi.org/10.1007/s10668-019-00565-4.

Sahu, A.S. (2014). Identification and mapping of the waterlogged areas in Purba Medinipur part of Keleghai river basin India: RS and GIS methods. International Journal of Advanced Geosciences, 2(2), 59-65. doi.org/10.14419/ijag.v2i2.2452.

Sharp, R., Douglass, J., Wolny, S., Arkema, K., Bernhardt, J., Bierbower, W., Chaumont, N., Denu, D., Fisher, D., Glowinski, K., Griffin, R., Guannel, G., Guerry, A., Johnson, J., Hamel, P., Kennedy, C., Kim, C.K., Lacayo, M., Lonsdorf, E., Mandle, L., Rogers, L., Silver, J., Toft, J., Verutes, G., Vogl, A.L., Wood, S., Wyatt, K. 2020. InVEST 3.9.1 post2+ug.gb8532be User's Guide. The Natural Capital Project, Stanford University, University of Minnesota, The Nature Conservancy, and World Wildlife Fund. 
Soriano, M., Hilvano, N., Garcia, R., Hao, A.J., Alegre, A., and Tiburan, C.L.Jr., 2019. Land Use/Land Cover Change

Detection and Urban Sprawl Analysis in the Mount Makiling Forest Reserve Watersheds and Buffer Zone, Philippines. Environments 6(2), 9. doi.org/10.3390/environments6020009.

Toru, T. and Kibret, K. 2019. Carbon stock under major land use/land cover types of Hades sub-watershed, eastern Ethiopia. Carbon Balance Manage 14,7. doi.org/10.1186/s13021-0190122-z.

Zhang, K., Thapa, B., Ross, M., Gann, D. 2016. Remote sensing of seasonal changes and disturbances in mangrove forest: a case study from South Florida. Ecosphere, 7(6), 23. doi: $10.1002 /$ ecs 2.1366 .

Zhao, Z., Liu, G., Mou, N., Xie, Y., Xu, Z., and Li, Y. 2018. Assessment of Carbon Storage and Its Influencing Factors in Qinghai-Tibet Plateau. Sustainability, 10(6), 1864. doi.org/10.3390/su10061864. 